\title{
Green Accounting Based with Analysis University- Based Social Responsibility At Small City
}

\author{
Dri Asmawanti S. ${ }^{1}$, Indah Oktari Wijayanti ${ }^{2}$, Novita Sari ${ }^{3}$ \\ The University of Bengkulu ${ }^{1,2,3}$ \\ \{driasmawantis@unib.ac.id¹,indahoktari24@gmail.com², novitasari@unib.ac.id³
}

\begin{abstract}
This research looks at whether the application of green accounting from the environmental awareness responsibility of the universities in Bengkulu City. The problem that is formulated is whether there is a difference between the application of green accounting-based university social responsibility between universities or campuses in Bengkulu City. The implementation of Green accounting is tested from environmental attention, environmental responsibility, environmental reporting, and environmental audit. The sample in the study involved 6 (six) universities in Bengkulu City. The results showed that there was a difference in the application of green accounting based on university social responsibility in universities in Bengkulu City. The first determinant factor in the application of green accounting in Bengkulu city is environmental attention, The Second Factor is environmental reporting, the third factor is environmental responsibility and the fourth factor is an environmental audit.
\end{abstract}

Keywords: Green accounting; Environmental Awareness; Environmental Responsibility; Environmental Reporting, and Environmental Audit

\section{Introduction}

The issue of green accounting raises public awareness of environmental sustainability for future human survival. This forces companies to adjust to an environmental issue, one of the adjustments that need to be made in accounting. Accounting science that studies specifically in the field of environment is called green accounting or known as environmental accounting. Green accounting relates to environmental information and environmental audit systems and has been defined as the identification, tracking, analysis, and reporting, and cost information related to the environmental aspects of an organization. The main role of green accounting is to address social environmental issues, as well as have an impact on the achievement of sustainable development and the environment in any country, which affects the behavior of the company in the face of social and environmental responsibility issues. Also, green accounting is used as an effort by the company to assist in achieving the company's goals towards responsibility to the company's stakeholders.

Lindrianasari (2007) terms with Environmental Accounting Disclosure. Besides, green accounting is also associated with Triple Bottom Line Reporting (Raar, 2002). This last term is also known as Social and Environmental Reporting wherein its financial reporting, the company reports the company's operational activity performance, environmental performance, 
and social performance. Other terms can also be used such as Environmental Accounting, Social Responsibility Accounting, and so on (Harahap, 2002). Social responsibility in universities is referred to as University Social Responsibilities or USR. It is essentially an ethical policy that affects the quality of the performance of the college community which includes students, managers, teachers, and all college employees through management responsible for the educational, cognitive, employment, and environmental impacts generated by universities through an interactive dialogue with the community to produce sustainable human development (Sari and Hadiprajitno, 2013).

According to De Beer and Friend (2006), one of the factors that can help improve environmental performance is environmental accounting. The role of environmental accounting in improving environmental performance refers to one of the accounting roles that is as an information provider for management. With environmental accounting, especially Environmental Management Accounting (EMA), environmental costs are identified, determined, and allocated appropriately to products or processes, enabling management to look for opportunities for cost savings. The EMA also provides information on the physical flow of materials, energy, and water used as well as waste and emissions generated, making it easier for management to conduct environmental management to improve environmental performance (Deegan, 2002). The subsystem of environmental accounting is Environmental Management Accounting. Meanwhile, Yousef (2003) states that three aspects of environmental accounting should be considered in its implementation, namely environmental attention, environmental responsibility, environmental accounting reporting, and environmental audit. Environmental management accounting can also be used as a benchmark in environmental performance.

Green campus is one of the achievements of green accounting where the university strives to green around the campus area to make employees, students, and others feel comfortable in the quality of the green environment. But not just on campus. Based on tri dharma universities namely education, research, and community service, Universitas Bengkulu (Unib) wants to improve quality in the field of education, research, and community service. This is evidenced by supporting the success of every program under the tri dharma of universities among others, programs that support academic development, community service programs around the University of Bengkulu, as well as helping students to support achievement at the National and International level by including students in championship activities in the field of research.

Many universities are already aware of USR, one of which is Bengkulu University. This form of environmental awareness by the campus is greening in the campus environment, one of which is seen from the availability of bicycle-only parking. However, awareness of its environment has not been fully realized. Some of the complaints expressed by the campus community are the lack of trash cans, the cleanliness of the bathroom, classrooms that are not uncommon to be mosquito dens. The lecture hall is quite large, but the air ventilation is inadequate, so there is no air exchange and often feels hot. The parking lot in some faculties looks untidy, hot, and chaotic. Some of those problems raise the question of the extent of environmental concern and concern as a form of implementation of Green Accounting based on University Social responsibility for the academic community in universities in Bengkulu City. The purpose of this research is to analyze the implementation of green accounting applied by universities in Bengkulu city based on university social responsibility. In addition to identifying green accounting factors in universities in Bengkulu city-based University Social Responsibilities (USR). 


\section{Theoretical Framework and Hypotheses}

The theory of legitimacy confirms that companies continue to strive to ensure that they operate within the frames and norms that exist in the society or environment in which the company is located, where they seek to ensure that their activities (the company) are accepted by outsiders as a "legitimate" one (Deegan, 2004). Ghozali and Chariri (2007) stated that the theory of legitimacy was the "social contract" that occurs between the company and the society in which the company operates and uses economic resources. Stakeholder theory holds that the company is not an entity that only operates for its benefit but provides benefits to stakeholders (Chariri, 2007). Stakeholder theory is a theory that explains how the management of the company meets or manages the expectations of stakeholders. Stakeholder theory emphasizes the importance of accountability of organizational accountability far beyond financial or economic performance. This theory states that organizations will choose to voluntarily disclose information about their environmental, social, and intellectual performance, above and above its mandatory request, to meet the actual or expected expectations of stakeholders (Deegan, 2004). The Institutional theory holds that organizations that prioritize legitimacy will tend to try to adjust to external expectations or social expectations of where the organization is located (DiMaggio and Powell, 1983). Institutional Theory is the formation of an organization due to institutional environmental pressures that lead to institutionalization. Zukler (1987) in Ridha (2012), states that ideas or ideas in institutional environments that form language and symbols that explain the existence of the organization and are accepted as norms in the concept of organization.

\subsection{Environmental Awareness}

Attention is part of attitude or behavior. The concern that exists from attitude becomes true if every behavior shown continues to increase and become the nature of his life. An example associated with the environment is the prohibition of not disposing of garbage to the river/channel, then as an environmentally conscious human being must obey the prohibition by not throwing garbage into the river. It is said that because according to the theory, attention is the knowledge that is part of an attitude or action. Furthermore, according to Salim (1982), environmental awareness is an effort to raise awareness to not only know about garbage, pollution, greening, and protection of rare animals but more than all of it, raising awareness of the Indonesian human environment, especially today's youth to love the homeland. Therefore the college should pay its attention to awareness and commitment to the importance of University Social Responsibility (USR). Focusing on these variables is the condition that causes respondents' attention to environmental issues.

$\mathrm{H}_{1}$ : There is a Difference in Environmental Awareness between the academic community in universities in Bengkulu

\subsection{Environmental Responsibility}

Environmental Responsibility and Engagement is the Company's commitment to participate in sustainable economic development to improve the quality of life and environment that benefits, both for the Company itself, the local community, and the community at large (Musyarofah 2013). The organization's social responsibility arises in 
response to or proactive actions taken by the organization towards the expectations of the community for the implementation of the activities carried out. The development of people's expectations through three important stages is, first, people's expectations are limited to traditional economic functional problems; second, the public recognizes the company's responsibility to perform economic functions with an awareness of changing goals, values, and social demand; third, the community expects the company to help achieve community goals.

$\mathrm{H}_{2}$ : There is a difference between the academic community in universities in Bengkulu.

\subsection{Environmental Reporting}

Adam and Zutshi (2006) delivered benefits for companies to implement and report on their CSR activities namely better employee recruitment and retention, better internal decisionmaking and cost savings, better reputation and relationships with stakeholders, and higher financial returns. Thus it can be concluded that transparent and accountable CSR reporting will encourage the implementation of CSR activities, which will ultimately increase not only the value of the company but also the welfare of the community.

$\mathrm{H}_{3}$ : There is a Difference in Environmental Reporting between the academic community in universities in Bengkulu

\subsection{Environmental Audit}

Environmental auditing is a systematic process that needs to be carefully planned, structured, and organized. Since environmental audits are part of the long-term evaluation and vetting process, it should be a repetitive process so that, if necessary different groups can repeat them and compare results to reflect quantitative and qualitative changes (Hemmatfar and Salehi, 2011).

$\mathrm{H}_{4}$ : There is a Difference in Environmental Audit between the academic community in universities in Bengkulu

\section{Methods}

This research is quantitative descriptive research. The data used in this study is the primary data. The method of data collection for this study is to use questionnaires. The questionnaire contains questions related to the responsibility of the academic community in managing the environment of the surroundings of the college. Hypothetical testing in this study uses the Anova One-Way Method. The population in this study is universities in Bengkulu. Sampling in this study using the Convenience Sampling technique which is sampling based on the ease of researchers (Mustafa, 2000). Therefore, this research sample was conducted at 6 (six) universities in Bengkulu City. The pattern of dissemination of questionnaires is carried out by the axial sampling method. Besides axial is anyone who happens to meet with researchers can be sampled, if viewed by the person encountered it is suitable as a data source (Sugiyono, 2001). The data source uses quantitative data obtained from the respondent's answer. The data source used in this study is the primary data. Primary data is data obtained directly from the source (research object). In this study, the data used was a questionnaire or questionnaire (attached). Questionnaires were obtained from previous studies. Respondents' answers were measured based on a Likert scale to express a good equation in the form of a comparison with 
the gap, by choosing an alternative between 1 to 5 of value: Answer strongly disagree (score 1), Answer disagree (score 2), Neutral answer (score 3), Answer agree (score 4), Answer strongly agree (score 5).

The operational definitions of the variables used in this study are as follows:

a. Environmental Attention, an instrument used to measure the company's awareness of the environment consists of 8 question items that Teoh and Thong developed (1986) in Yousef (2003).

b. Environmental Responsibility, According to Harahap (2002) suggests that the company should have a social attitude and responsibility that is, social engagement is a response to the desires and expectations of the community long term. It is a very profitable company. But social engagement will probably affect the improvement of the environment, society, which will probably decrease production. This variable measurement uses 5 question items that Teoh and Thong developed (1986) in Yousef (2003).

c. Environmental Reporting, on the measurement of these variables using 10 question items developed from Dunk research (2002).

d. Environmental Audit, required as an evaluation process carried out by the business person and or activities to establish the level of non-compliance with the laws and regulations in the field of management of life support related to the activity (Ministry of Environment). This variable measurement uses 3 question items developed by Sari and Hadiprajitno (2013).

The data analysis technique used in this study is a descriptive analysis that focuses on the causes of the emergence of attention from the unit leadership on environmental issues, what conditions most affect university leaders for attention to environmental issues and how much attention it is. as well as environmental concerns, environmental responsibilities, environmental reporting, and environmental audits. Analyze data using the One-Sample TTest Method. This test is part of the parametric inference statistics (different tests). The requirements that must be met for this test are quantitative data, normality tests and data must be similar/homogeneous. The basis of decision-making is if the value of significance over Sig. (2-tailed) $>0.05$, then $\mathrm{H}_{0}$ is accepted and $\mathrm{H}_{\mathrm{a}}$ is rejected, and If the value of significance over Sig. (2-tailed) $<0.05$, then $\mathrm{H}_{0}$ is rejected and $\mathrm{H}_{\mathrm{a}}$ is accepted.

\section{Results and Discussion}

The population in this study is all academic staff, students and lecturers at universities in Bengkulu City. The sample in this study is academic staff, students and lecturers who are on the list of universities in Bengkulu City is Universitas Bengkulu, Universitas Muhammadiyah Bengkulu, Universitas Prof. Dr. Hazairin, SH, Sekolah Tinggi Ilmu Kesehatan Bhakti Husada Bengkulu, Kota Bengkulu, Sekolah Tinggi Ilmu Kesehatan Tri Mandiri Sakti Bengkulu, Kota Bengkulu and Institut Agama Islam Negeri Bengkulu. The sample in this study was 300 which determined as many as 50 samples for each college. The data collected from the questionnaire that has been filled in by resonden obtained the identity data of the respondent as follows:

Tabel 1. Tingkat Pengembalian Kuesioner

\begin{tabular}{cccc}
\hline \multirow{2}{*}{ Instansi } & \multicolumn{2}{c}{ Kuesioner } & \multirow{2}{*}{ Tingkat Pengembalian (\%) } \\
\cline { 2 - 3 } & Disebarkan & Kembali & \\
\hline UNIB & 50 & 40 & 80 \\
IAIN & 50 & 50 & 100 \\
\hline
\end{tabular}




\begin{tabular}{cccc}
\hline \multirow{2}{*}{ Instansi } & \multicolumn{2}{c}{ Kuesioner } & \multirow{2}{*}{ Tingkat Pengembalian (\%) } \\
\cline { 2 - 3 } & Disebarkan & Kembali & \\
\hline STIKES TRI SAKTI MANDIRI & 50 & 50 & 100 \\
STIKES & 50 & 50 & 100 \\
UMB & 50 & 50 & 100 \\
UNIHAZ & 50 & 34 & 68 \\
TOTAL & 300 & 274 & 91,3 \\
\hline
\end{tabular}

Based on the table above, we can conclude that the questionnaire return rate is $91.3 \%$. This means that almost the entire questionnaire can be taken directly from the respondent. Based on the questionnaire spread obtained a description of respondents based on gender as follows:

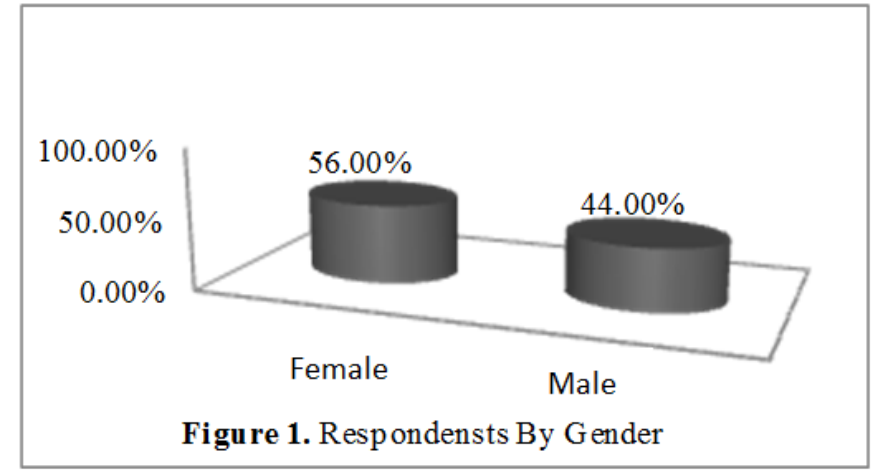

Fig. 1. Respondents By Gender

Based on data from the gender respondents described that of the 274 respondents, 153 people $(56 \%)$ among them are female and 121 people $(44 \%)$ among them are male. This means that all universities in Bengkulu do not have gender in decision making in socialenvironmental responsibilities at the university, all are involved in USR activities and have their share of responsibilities. Respondent data based on 3 positions, namely Students, Lecturers and Employees. Here's an overview of the data:

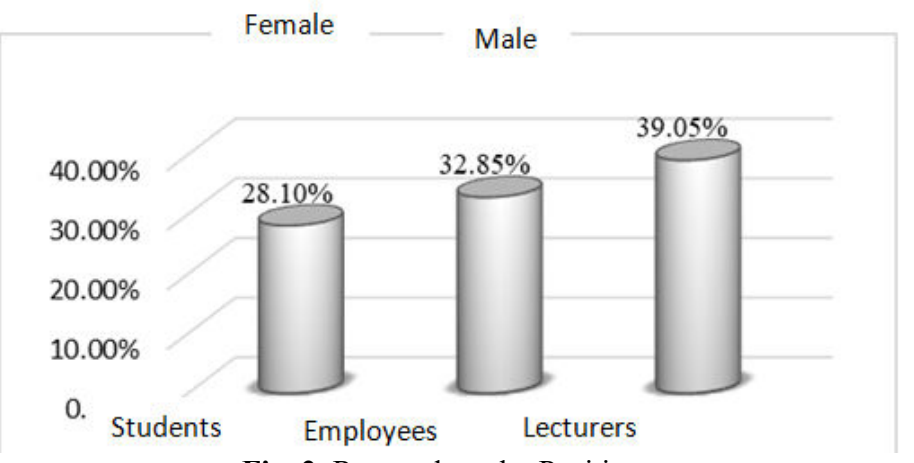

Fig. 2. Respondents by Position

Based on the above image of the respondents from the last education that out of 274 respondents, who became students consisted of 77 people $(28 \%)$, employees as many as 90 
people (32.85\%) lecturers as many as 107 people (39.05\%). Based on the questionnaire, a description of respondents was obtained based on the following age:

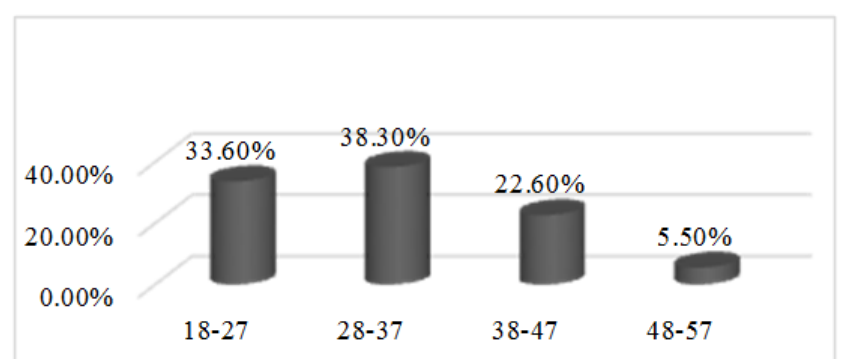

Fig. 3. Respondents by Age

Based on respondents' data from that age of 274 respondents, the age of respondents aged 18 - 27 years was $33.6 \%$, and those aged $28-37$ by $38.3 \%$, and those aged $38-47$ by $22.6 \%$ while those aged $48-57$ by $5.5 \%$. It is likely that respondents can provide objective answers to the questions asked as well as the level of mature thinking that will allow the respondent to work well in completing the charged work. The following is data on the level of dissemination and return of questionnaires that have been conducted.

\subsection{Hypothetical Test Results}

The entire complete data is processed with a previously constructed hypothesis. The results of "Green Accounting" in a college can be seen from many factors, one of which is how much attention the University has to its Environment. The results explained that the picture of four factors that had been hypothesized at the beginning showed quite high results on the implementation of Environmental reporting in universities in Bengkulu city in aggregate. The overall data, which can be processed in 274 samples, shows the highest average figures are on Environmental Reporting variables, compared to Environmental Concern, Environmental Responsibility and Environmental Audit. The significance of the environment reporting variable is 0.000 and the average value difference is 26.35 . While the least variable the average value of the difference is in the environmental audit variable, i.e. with a value of 10.16. Here are the results of processing the data;

Table 2. Different Test Results based on research variables

\begin{tabular}{lccc}
\hline Variabel & t & Sign. & Mean Difference \\
\hline PRHT & 72.596 & .000 & 27.175 \\
TGJW & 60.270 & .000 & 15.361 \\
PLPOR & 85.670 & .000 & 26.354 \\
AUD & 71.777 & .000 & 10.161 \\
\hline
\end{tabular}

When viewed from the results of statistical tests based on universities in Bengkulu Province shows the results that there is a difference of Environmental Concern between the academic community in Bengkulu city with a value of significance below 0.05 . The average difference between 6 (six) universities in Bengkulu is between 23.91 and 33.00. The most recent value was in Stikes Tri Mandiri Sakti with a value of 23,912 while The University of Bengkulu had the largest average value of 33.00. Thus the first hypothesis proved acceptable. The results of processing the data are as follows: 
Table 3. Different Test Results based on Environmental Concerns

\begin{tabular}{cccc}
\hline Variabel & $\mathbf{t}$ & Sign. & Mean Difference \\
\hline IAIN & 57.802 & .000 & 27.059 \\
STIKESTRI & 19.354 & .000 & 23.912 \\
STIKES & 31.427 & .000 & 25.912 \\
UMB & 19.459 & .000 & 24.118 \\
UNIHAZ & 58.320 & .000 & 31.294 \\
UNIB & 50.453 & .000 & 33.000 \\
\hline
\end{tabular}

The results of the data test on environmental responsibility variables, obtained test results there is a difference between the academic community of universities in Bengkulu with a level of significance below 0.05 . The highest average difference score was at Hazairin University with a score of 18,235, followed by The University of Bengkulu, IAIN, Stikes Tri Sakti Mandiri, and the lowest was in Peruguruan Tinggi Stikes with a score of 13,088. Thus obtained the result of the range of differences in the application of environmental responsibility in universities in Bengkulu city is between 13,088 to 18,235 . Based on the above results, this study can prove the second hypothesis is acceptable.

Table 4. Different Test Results based on Environmental Responsibility

\begin{tabular}{cccc}
\hline Variabel & $\mathbf{t}$ & Sign. & Mean Difference \\
\hline IAIN & 34.512 & .000 & 15.765 \\
STIKESTRI & 17.725 & .000 & 14.059 \\
STIKES & 20.978 & .000 & 13.088 \\
UMB & 17.696 & .000 & 13.706 \\
UNIHAZ & 35.142 & .000 & 18.235 \\
UNIB & 31.699 & .000 & 18.029 \\
\hline
\end{tabular}

The results of data analysis tests for environmental reporting variables show that there are differences in environmental reporting between the academic community at universities in Bengkulu. This is seen from the result of the level of significance of data processing which is smaller than 0.05 . The highest average application of environmental reporting was at Hazairin University (Unihaz) college of 30,324, and the smallest average score at STIKES college was 22,853. Thus the average application of Green Accounting is in the range of 22,853 to 30,324. Therefore, the second hypothesis proved acceptable.

Table 5. Different Test Results based on Environmental Reporting

\begin{tabular}{cccc}
\hline Variabel & $\mathbf{t}$ & Sign. & Mean Difference \\
\hline IAIN & 76.869 & .000 & 26.588 \\
STIKESTRI & 46.348 & .000 & 25.118 \\
STIKES & 22.531 & .000 & 22.853 \\
UMB & 35.137 & .000 & 25.000 \\
UNIHAZ & 49.714 & .000 & 30.324 \\
UNIB & 40.391 & .000 & 29.500 \\
\hline
\end{tabular}

Data processing for environmental audit variables shows significant results with a value of significance below 0.05. The average environmental audit score was between 9,088 and 11,382. The lowest score in Stikes is 9,088. The highest score of 11,382 is found in two universities, namely Bengkulu University and Hazairin University. Thus it can be concluded that there are differences in environmental audits between the academic community in universities in Bengkulu. Thus, it can be concluded that the fourth hypothesis proved 
acceptable. Here are the data test results:

Table 6. Different Test Results based on Environmental Audit

\begin{tabular}{cccc}
\hline Variabel & $\mathbf{t}$ & Sign. & Mean Difference \\
\hline IAIN & 76.869 & .000 & 26.588 \\
STIKESTRI & 46.348 & .000 & 25.118 \\
STIKES & 22.531 & .000 & 22.853 \\
UMB & 35.137 & .000 & 25.000 \\
UNIHAZ & 49.714 & .000 & 30.324 \\
UNIB & 40.391 & .000 & 29.500 \\
\hline
\end{tabular}

\subsection{Discussion}

The main role of Green Accounting in various universities is one of them to address various environmental problems faced by institutions, whose role has an impact on the achievement of sustainable development. In addition, Green Accounting is useful in helping the company achieve its objectives mainly responsible to the stakeholders of the company / institution. Perguruan Tinggi is one of the institutions that always strives to green around the campus with the aim of making its employees, students and the entire academic community feel comfortable with the quality of its beautiful campus environment. Several universities in Bengkulu city that were sampled in this study proved that the application of Green Accounting is applied in a good way and between universities in Bengkulu city has differences in its application. Green campus is one of the forms of universities to conduct social accountability (University Social Responseibility) to the community and its academic community. The college's concern for Green Accounting is reflected in four variable indicators that form the basis of its measurement, namely environmental attention, environmental responsibility, environmental reporting and audit. The results of testing statistical data through this quantitative method show that there are differences in the application of Green Accounting based on Univerisity Social Responsibility in universities in Bengkulu City. This shows that the application of Green Accounting between one college and another has different methods and ways of implementing it.

Applications that have a considerable degree of difference in universities in the implementation of Green Accounting are environmental concerns, and the lowest level of difference is environmental audit. This shows that the level of environmental attention between universities in Bengkulu city has quite different applications far. High environmental awareness shows that the college has concerns for waste management, pollution, greening, protection of rare animals and has a spirit of love for the homeland (Salim, 1982). While the environmental audit variables that have a small average of implementation show that there is not much variation to the systematic process that needs to be planned, carefully organized in the environmental evaluation process both long-term evaluation and in the inspection process (Hemmatfar and Salehi, 2011).

Environmental reporting based on University Social Responsibility (USR) shows quite significant results applied in universities throughout Bengkulu. This means that several universities in Bengkulu city have reported their social accountability activities. Transparent and accountable reporting can increase institutional value and also affect people's well-being (Adam and Zutshi, 2006).

Based on the second hypothesis, it results that there is a difference in environmental responsibility between the academic community in universities in Bengkulu. The environmental responsibility of an institution is a proactive response by the organization to the 
community's expectations for the implementation of its activities. Of course, the responsibility of this environment is also able to provide answers to the expectations of people who hope that an institution must have great care and responsibility towards its social (Musyarofah, 2013).

Based on the above statistical test results we can identify green accounting implementation factors are environmental attention, environmental reporting, environmental responsibility and environmental audit. The level of concern of universities in the implementation of Green Accounting is the University of Bengkulu and Hazairin University. While Stikes Bhakti Husada has the lowest average score compared to other universities.

\section{Conclusion}

This research proves that some universities in Bengkulu city that were sampled in this study implemented Green Accounting in a good way and between universities in Bengkulu city have differences in its application. The results of the test against the research hypothesis prove that the four indicators of Green Accounting proved to differ between the academic community in universities in Bengkulu City, both environmental attention variables, environmental responsibility, environmental reporting and environmental audits. This research tested the application of Green Accounting in universities throughout Bengkulu. To the perfection of this study, researchers suggest for further analysis can use regression methods or correlations with other variables. Furthermore, research can also be developed using qualitative methods so that the discussion of Green Accounting implementation can be deepened again with a variety of good approaches and analytical.

\section{References}

[1] Adams, C. dan Zutshi, A..: Why Businesses Should Act Responsibly and Be Accountable. Accountants Today, 32: 25-28 (2006)

[2] Astiti, Widhiyanti :Implementasi Green Accounting Berbasis University Social Responsibility (Usr) Di Universitas Negeri Yogyakarta. Jurnal Nominal.Vol.III No. 2 Tahun 2014 (2014)

[3] De Beer, P. dan F. Friend: Environmental Accounting: A Management Tool for Enhaching Corporate Environmental and Economic Performance. Ecological Economics 58: 548-560 (2006)

[4] Deegan, C.: "Financial Accounting Theory". Mc Graw-Hill Book Company, Sydney (2004)

[5] Deegan, C.: The Legitimising Effect of Social and Environmental Disclosures- A Theoretical Foundation. Accounting, Auditing \& Accountability Journal 15(3): 282311 (2002)

[6] DiMaggio, P.J. dan W.W. Powell : The Iron Cage Revisited: Institutional Isomorphism and Collective Rationality in Organizational Fields. American Sociological Review (1983)

[7] Dunk, Allan .S.: "Product Quality, Environmental Accounting, and Quality Performance. Accounting, auditing \& accountanility journal, vol 15 No 5pp 719-732 (2002)

[8] Ghozali, I. dan Castellan : Statistik Non.Parametrik: Badan Penerbit UNDIP (2002) 
[9] Ghozali, Imam dan Anis Chariri: Teori Akuntansi. Semarang: Badan Penerbit Universitas Diponegoro (2007)

[10] Harahap, Sofyan Syafri :Teori Akuntansi.Raja Gafindo Persada. Jakarta (2001)

[11] Hemmatfar, Mahmood, Ph.D. \& Salehi M, Ph.D.: Competitive Advantages and Strategic Information Systems International. Journal of Business and Management Vol. 5, No. 7 (2011)

[12] Lindrianasari : Hubungan antara Kinerja Lingkungan dan Kualitas Pengungkapan Lingkungan dengan Kinerja Ekonomi Perusahaan di Indonesia". JAAI. Vol 11. No2 (2007)

[13] Musyarofah, Siti : Analisis Penerapan Green Accounting di Kota Semarang”. Journal AAJ 2 (3)(2013), Universitas Negeri Semarang (2013)

[14] Raar, Rineka J. : Environmental initiatives: Towards triple-bottom line reporting. Corporate Communications. Bradford: Vol.7, Iss. 3; pg. 169, 15 pgs (2002)

[15] Ridha, M. Arsyadi dan Hardo Basuki: Pengaruh Tekanan Eksternal, Ketidakpastian Lingkungan, dan Komitmen Manajemen terhadap Transparansi Pelaporan Keuangan (2012)

[16] Sari, M. P dan Hadiprajitno, P. B.:Pengawasan Implementasi "Green Accounting" Berbasis University Social Responsbility (USR) di Universitas Negeri Semarang Serta Studi Komparasi Universitas Se-Kota Semarang”. Jurnal Akuntansi \& Auditing. Vol. 9 No.2 (2013)

[17] Sugiyono: Statistika untuk Penelitian. Bandung: Alfabeta. Undang-Undang Nomor 40 Tahun 2007 Pasal 74 Tentang tanggungjawab sosial dan lingkungan (2001)

[18] Yousef F. H.: "Green Accounting in Developing Countries: The Case of U.A.E and Jordan”. Manajerial Finance. Vol. 29, No. 8 (2003) 